\title{
Effectiveness of Programmed Learning Material in Learning Cognitive Domain of B.Ed Students
}

\author{
Jignasa H. Joshi ${ }^{1 *}$
}

\section{ABSTRACT}

The present teaching techniques needs revised thinking to make learning more effective for students. In fact the teaching methodology should be such by which the students can be involved in reading, thinking, problem solving and then learning by their own efforts. It becomes more important at B.Ed. Level. For this purpose self-learning method is a very effective media. There are several Self Learning Techniques in which learner can learn by their own pace. Inamdar, J.A (1981), Suthar, K.S (1981), Debi Meena Kumari (1989), concluded that Programmed learning method was more effective. Can the learning of cognitive domain be made easier by using Programmed Learning Material? Is the Programmed Learning Method similarly effective for boys and girls? The investigator has thought about all such crucial questions for undertaking this research. Hence the topic "Effectiveness of Programmed Learning Material in Learning Cognitive Domain of B.Ed Students” is selected for the presentation.

Keywords: PLM-Programmed Learning Material.

Bloom's Taxonomy was created in 1956 under the leader's hip of Dr Benjamin Bloom in order to promote higher forms of thinking in education, such as analyzing and evaluating concepts, processes, procedures, and principles, rather than just remembering facts (rote learning). It is most often used when designing inst ruction or learning processes ( Instructional Design)

Researcher selected this cognitive domain because it involves knowledge and the development of intellectual skills (Bloom, 1956). This includes the recall or recognition of specific facts, procedural patterns, and concepts that serve in the development of intellectual abilities and skills. There are six major categories of cognitive processes, which are listed in order below, starting from the simplest to the most complex. The categories can be thought of as degrees of difficulties. That is, the first ones must normally be mastered before the next one can take place.

\footnotetext{
${ }^{1}$ Head of Department, Kadi Sarva Vishwavidyalaya, Gandhinagar, Gujarat \& India

*Responding Author

(C) 2016 I J Joshi; licensee IJIP. This is an Open Access Research distributed under the terms of the Creative Commons Attribution License (http://creativecommons.org/licenses/by/2.0), which permits unrestricted use, distribution, and reproduction in any Medium, provided the original work is properly cited.
} 


\section{Statement of the Problem}

Effectiveness of Learning Cognitive Domain of B.Ed Students through Programmed Learning Material

\section{OBJECTIVES}

The researcher decided the following objectives for the present study.

1. To study the effectiveness of Program Learning Material in learning Cognitive Domain of B.Ed. Students

2. To compare the effectiveness of Program Learning Material on the academic achievement of Male \& Female students of B.Ed in learning Cognitive Domain

\section{Hypotheses}

The following hypotheses were prepared for the present study.

HO1 There is no significant difference in the mean score academic achievement of Experimental and Control Test.

HO2 There is no significant difference in the mean scores of academic achievement of Male and Female students of B.Ed learnt through Program Learning Material.

\section{Limitation and Delimitation}

- The strength of B.Ed students was 92 in Indian Institute of Teacher Education, which were selected as a sample in this research, but data is collected and treatment could be given to 46 students out of 92 thus remains the limitation of the study.

- The study is delimited to the students of Indian Institute of Teacher Education English Medium B.Ed College Gandhinagar City.

\section{Definition of Key-words}

1) Academic Achievement: Academic Achievements refers to the scores obtained on self constructed achievement in the form of restricted response item (MCQ \& Fill in the Blanks).

2) B.Ed Students - B.Ed Students refers to the students of education, studying in B.Ed English Medium College at Gandhinagar City.

3) Effectiveness - Effective refers to the difference between the mean scores of Academic Achievement of Experimental Group and Control Group.

\section{Variable}

The following are the variables included in the present study.

\section{Independent Variable:}

Programmed Learning Method

\section{Dependent Variable:}

Academic Achievement of the B.Ed Students

\section{Moderate Variable: (Sub-Independent Variable)}

Gender: Male (A1) , Female (A2) 


\section{Control Variable:}

1) Gandhinagar City.

2) B.Ed English Medium College.

3) B.Ed Students.

4) Co - Educated College

\section{Population and Sample}

Population for the present study was - All the Students of Indian Institute of Teacher Education of Gandhinagar City studying in B.Ed. The B.Ed trainees of the year 2014 - 2015 were included in the population. The selection of sample was done by Purposive Sampling Technique. The strength of B.Ed students in Indian Institute of Teacher Education were 92 which were divided in to two equal groups through random sampling.

\begin{tabular}{|ll|l|l|}
\hline Method & $\longrightarrow$ & Experimental Group & Control Group \\
\hline Gender & & 12 & 19 \\
\hline Male & & 34 & 27 \\
\hline Female & 46 & 46 \\
\hline Total & 46 &
\end{tabular}

\section{Research Method and Research Design:}

Experimental Method of Research was used for the present study. The experiment of the present research was to check the effectiveness of PLM for learning Cognitive domain for B.Ed. Trainees For the present study the researcher selected True - Experimental design post test two equivalent group design.. The figurative description of which can be made as given below.

\begin{tabular}{|l|l|l|}
\hline Group & Treatment & Post Test \\
\hline E & $\mathrm{X}_{1}(\mathrm{PLM})$ & $\mathrm{T} 2$ \\
\hline $\mathrm{C}$ & - & $\mathrm{T} 2$ \\
\hline
\end{tabular}

\section{Treatment:}

The researcher went through the syllabus of B.Ed which was prescribed by their universities and then went through many references materials such as textbooks, internet etc. It was found that the students of B.Ed faced many difficulties in understanding the concept of Cognitive Domain of Bloom's Taxonomy and not able to use it in an accurate way in their lessons for developing higher level thinking among their students. The researcher thought that the use of new technologies is one of the innovative ways for teaching cognitive Domain of Bloom's Taxonomy. With a view to overcome the problem the researcher had tried a humble and sincere effort to teach methodology content through Program Learning Material. 


\section{Tools for Data Collection}

For Data Collection researcher Constructed teacher made Post test on the basis of blue print. In which 20 Questions were asked. Equal mark (1) was given to each question. The post test was of multiple choice questions type.

\section{Data Analysis}

To access the effectiveness of PLM t-value was found.

$>$ For rejection or acceptation of hypothesis t-value was found Hypothesis wise.

\begin{tabular}{|c|c|c|c|c|c|c|c|}
\hline Hypothesis & Group & $\mathbf{N}$ & $\mathbf{M}$ & SD & SED & C.R. & Remarks \\
\hline \multirow[b]{2}{*}{$\mathrm{Ho}_{1}$} & Control Group & 46 & 7.93 & 1.90 & \multirow[b]{2}{*}{0.32} & \multirow[b]{2}{*}{35.31} & \multirow[b]{2}{*}{$\begin{array}{l}\text { Significant at } \\
0.01 \text { level }\end{array}$} \\
\hline & $\begin{array}{l}\text { Experimental } \\
\text { Group }\end{array}$ & 46 & 19.09 & 0.98 & & & \\
\hline \multirow{2}{*}{$\mathrm{Ho}_{2}$} & $\begin{array}{l}\text { Male of Exp. } \\
\text { Group }\end{array}$ & 19.00 & 12 & 1.28 & \multirow{2}{*}{0.40} & \multirow{2}{*}{0.29} & \multirow{2}{*}{$\begin{array}{l}\text { No } \\
\text { Significant } \\
\text { Difference }\end{array}$} \\
\hline & $\begin{array}{l}\text { Female of Exp. } \\
\text { Group }\end{array}$ & 19.12 & 34 & 0.88 & & & \\
\hline
\end{tabular}

\section{FINDINGS}

Experimental group was better than control group students on academic achievements of Program Learning Material in learning Cognitive Domain of B.Ed students.

There was no real difference between male and female on academic achievements of Program Learning Material in learning Cognitive Domain of B.Ed students.

\section{EDUCATIONAL IMPLICATION}

The educational implications of the present research are as mentioned below.

Such programmes are very helpful for curriculum development as curriculum developers can make use of such self learning devices in curriculum development.

The Program is useful for classroom teaching.

Promotes situated and authentic learning.

Promotes learning from multiple perspectives and contexts.

\section{CONCLUSION}

From the Conclusion and finding obtain from study we can say that PLM is far effective than traditional method, Hence such a new innovative experiments should be go on in future New researches play an important role for the development and progress of the nation. In the present study the findings of the study, educational implications and suggestions are provided or study. The present study will prove helpful for the teachers, students, government and educational implications. 


\section{REFERENCE}

Agrawal J. C. (1996), Education Research and Introduction, New Delhi :Arya Book Depot.

Borg Water R. (1996); Educational Research in Introduction, New Delhi :Arya Book Depot.

Madan Lal (2007); Essential of Educations Technology, (Delhi: Anmol Publications)

E.N Teril (1960); Webster’s New Illustrated Dictionary, (New York:Book Inc),P.313.

Janardan Prasad Vijay Kumari (2005); Advanced Educational Technology, (Delhi: Kanishka Publisheres) 